\title{
Antyk jako źródło inspiracji w hitlerowskich Niemczech
}

Agnieszka Wypiorczyk*

\section{O inspiracji}

Inspiracja to pojęcie budzące pozytywne konotacje. Przeważnie rozumiana jest jako natchnienie autora oraz źródło jego wzorców. Daje mu impuls do tworzenia nowych dzieł, a w chwilach wypalenia pobudza jego zapał. Najczęściej używamy tego terminu w kontekście literackim. Niejednokrotnie w notce biograficznej jakiegoś pisarza można przeczytać o jego kręgach inspiracji, które zachęcały go do pisania czy też motywowały w trudnych chwilach. Jednak pojęcie to funkcjonuje także i na innych płaszczyznach. Jedną z nich jest płaszczyzna historyczna. Istnieje wiele przykładów potwierdzających tezę, że ludzie od zawsze czerpali wiedzę z doświadczenia historii. Nauka ta przybierała wielorakie formy. W główniej mierze snuli wnioski i uczyli się na jej błędach. Niekiedy wzorowali się na niej. Taka właśnie sytuacja miała miejsce w Trzeciej Rzeszy.

\section{Wprowadzenie do bistorii Trzeciej Rzeszy}

Trzecia Rzesza jest nieoficjalnym określeniem funkcjonującym w odniesieniu do Państwa Niemieckiego pod rządami Adolfa Hitlera jako kanclerza i Führera Rzeszy w latach 1933-1945. Było to państwo o ustroju

* Uniwersytet Lódzki, Wydział Filologiczny, Instytut Filologii Germańskiej, Zakład Językoznawstwa Niemieckiego, 90-236 Lódź, ul. Pomorska 171/173, e-mail: agnieszka.wypiorczyk@uni.lodz.eu. 
totalitarnym. Jego podstawy ideologiczne w głównej mierze opierały się na ideologii volkistowskiej ${ }^{1}$, która sięga korzeniami końca XIX wieku. Implikowała ona antysemityzm, skrajny nacjonalizm oraz założenie o istnieniu rasy panów mistycznie powołanej do panowania nad innymi ${ }^{2}$. Przedstawiciela rasy panów utożsamiał Aryjczyk ze wzorem prawdziwego Germanina, charakteryzującego się blond włosami, niebieskim oczami, wysokim wzrostem oraz proporcjonalną budowa ciała ${ }^{3}$. W czasie narodowego socjalizmu ideologia ta została ponownie wskrzeszona przez Alfreda Rosenberga, głównego teoretyka ideologii nazistowskiej. Dążenia nazizmu do zachowania czystości rasy miały usprawiedliwiać stosowanie eugeniki oraz eksterminacji słabszych jednostek, utożsamianych z Żydami i Słowianami ${ }^{4}$.

Swoją drogę do władzy naziści oparli przede wszystkim na krytyce postanowień traktatu wersalskiego, do których należały m.in. obarczenie Rzeszy winą za I wojnę światową, nakazanie wypłaty odszkodowań, zredukowanie liczebności armii, zakaz posiadania czołgów i lotnictwa oraz straty terytorialne. Wraz z wejściem w życie postanowień traktatu wersalskiego w Niemczech została ustanowiona republika ${ }^{5}$. Zmiany te skutkowały osłabieniem Rzeszy Niemieckiej oraz godziły w dumę narodową i niemiecki imperializm. Z tego też powodu propaganda skierowana przeciwko republice weimarskiej, a także propagowanie „ciosu w plecy", odegrały istotną rolę w promowaniu programu partii wśród wyborców i w znacznym stopniu przyczyniły się do zdobycia władzy przez NSDAP.

To właśnie niemiecki imperializm pełnił kluczową funkcję w zdobywaniu władzy, wprowadzaniu planów wyborczych partii, a także w inspiracjach narodowego socjalizmu. Stanowił on dla Adolfa Hitlera pod-

1 Niemieckie określenie tego pojęcia to völkische Ideologie.

2 Zob. J. Wieliczka-Szarek, III Rz̨esza. Narodżiny i żmierz̧ch sz̧aleństwa, Kraków 2006, s. 9.

3 Ibidem, s. 11.

4 Ibidem, s. 9.

5 Ibidem, s. 19-20.

6 Legenda o ciosie w plecy (niem. Dolchstosslegende) - mit propagowany przez przeciwników Republiki Weimarskiej, opowiadający o tym, że przegrana w I wojnie światowej była wynikiem zdrady cesarza przez polityków. Zdrada ta polegała na negocjowaniu pokoju bez udziału armii. Mit miał na celu przeniesienie winy za klęskę ze sfer wojskowych na sfery polityczne i cywilne. Zob. R. S. Rose, Krytyczny stownik mitów i symboli naziżmu, tłum. Z. Jakubowska, A. Rurarz, Warszawa 2006, s. 57-60.

Agnieszka Wypiorczyk · Antyk jako źródło inspiracji w hitlerowskich Niemczech 
łoże dążeń do dominacji nad Europą. Do jego największych wzorów i ideałów należała postać niemieckiego cesarza Fryderyka II Wielkiego, za którego rządów Prusy stały się potęga na arenie międzynarodowej. Gloryfikowano go do takiego stopnia, że w czasach narodowego socjalizmu stał się obiektem kultu. Działo się to z uwagi na konotacje, jakie budził. Wspomnienie Fryderyka II Niemcy kojarzą przede wszystkim z żelazną dyscypliną oraz imperialistycznym militaryzmem - cechami, których szczególnie pożądano w okresie Trzeciej Rzeszy. Sam Hitler utożsamiał się z Fryderykiem Wielkim do tego stopnia, że był głęboko przekonany o istnieniu analogii między jego losem a losem tego niemieckiego cesarza?.

Propaganda związana z Fryderykiem II, która z uwagi na sympatię narodu niemieckiego do tej postaci została dobrze przyjęta przez wyborców, w znacznej mierze przyczyniła się do rozpowszechniania kultu wodza, co stanowiło priorytet dla Hitlera ${ }^{8}$. On sam kreował siebie na Führera ${ }^{9}$, który w przyszłości znów przywróci Niemcom dawną chwałę. Wśród członków partii NSDAP ${ }^{10}$ panowało przekonanie o mistycznym powołaniu Hitlera do bycia wodzem. Skutkowało to powstaniem kultu jego osoby obdarzonej szczególnymi predyspozycjami do rządzenia. Ponadto na skutek zmian ustrojowych (upadek Cesarstwa Niemieckiego) i kryzysu gospodarczego w Niemczech wykształciła się tęsknota za autorytarną jednostką, która to, obok wodzowskich aspiracji Hitlera, przyczyniła się do zdobycia władzy przez NSDAP ${ }^{11}$.

\section{Inspiracje antykiem w narodowym socjalizmie}

Reprezentujący siłę i autorytet wodza Fryderyk II Wielki nie był jedynym źródłem inspiracji w narodowym socjalizmie. Naziści nigdy nie ukrywali, że źródło swojego natchnienia czerpią z czasów antycznych. Hitler

7 Zob. ibidem, s. 79-81.

8 Ibidem.

9 Niem. Führer - wódz.

10 Narodowosocjalistyczna Niemiecka Partia Robotników - faszystowska partia sprawująca władzę w Niemczech w latach 1933-1945.

11 Zob. M. Maciejewski, Kult Führera wśród narodowych socjalistów do 1933 r., [w:] Faszyzm niemiecki zperspektyny pótwiecza, red. A. Czubiński, Poznań 1985, s. 54-57. 
w swojej autobiograficznej książce Mein Kampf, będącej zarazem wykładnią ideologii nazistowskiej, pisał, że:

Historii nie studiuje się zwykle po to, aby odkryć, co się wydarzyło, ale po to, aby mogła ona dawać wskazówki na przyszłość i pomagała w kontynuowaniu egzystencji naszego własnego narodu. Nie powinna być oderwana od studiowania starożytności. Historia rzymska, właściwie ujęta według odpowiednich zasad, może być uważana za najlepszą instrukcję nie tylko teraz, ale dla wszystkich okresów ${ }^{12}$.

Cytat ten w szczególności podkreśla fakt, jak wielką rolę naziści przypisywali czasom starożytnym i w jakim stopniu czerpali z doświadczenia dziejów. Hitler wielokrotnie podkreślał, jak ogromne znaczenie mają dla niego losy starożytnego Rzymu. Miało to miejsce także w prywatnych rozmowach, chociażby z Reichsführerem SS Heinrichem Himmlerem, prowadzonej w głównej kwaterze Führera 2 listopada 1941 roku: „Do dziś rzymskie mocarstwo światowe nie ma sobie równych. Jak dokładnie zapanowano nad wszystkimi sąsiadującymi ludami - i nie ma państwa, które by wytworzyło tak jednolitą kulturę!"13.

Na podstawie przytoczonych cytatów można jednoznacznie zauważyć, że cywilizacje starożytne były wzorem, który narodowi socjaliści starali się naśladować. Jednakże opierało się to głównie na chęci utworzenia imperium obejmującego całą Europę, a nie na wartościach, które reprezentowały antyczne kultury.

Najbardziej wyraźnym nawiązaniem do czasów starożytnych było powitanie nazistowskie, tzw. Hitlergruß bądź deutscher Gruß. Powitanie to, polegające na podniesieniu w górę prawego ramienia z dłonią zwrócona do dołu, było powitaniem cezara w czasach Cesarstwa Rzymskiego. Początkowo było zapożyczone przez faszyzm włoski i miało nawiązywać do szczytnej historii tego kraju. W nazistowskich Niemczech występowało w akompaniamencie okrzyku Heil!, względnie Heil Hitler! Było to pozdrowienie zarówno cywilne - obowiązywało urzędników publicznych oraz zwykłych obywateli, jak i militarne - zastępowało całkowicie salutowanie. Nazistowskie powitanie było na tyle widoczne, że z daleka można

12 A. Hitler, Moja walka, tłum. I. Puchalska, P. Marszałek, Krosno 1992, s. 166.

13 A. Hitler, Rozmowy przy stole 1941-1944. Rozmowy w Kwaterze Gtównej zapisane na polecenie Martina Bormanna przezjego adiutanta Heinricha Heima, tłum. zespół, red. S. Dejkało, Warszawa 1996, s. 123.

Agnieszka Wypiorczyk · Antyk jako źródło inspiracji w hitlerowskich Niemczech 
było zobaczyć, kto uchyla się od podniesienia ręki, co było aktem buntu przeciwko reżimowi i braku chęci podporządkowania się. Zaskakujący jest jednak fakt, że pozdrowienie nazistowskie pełniło także funkcję ostracyzmu. Działo się to w przypadku więźniów, których obowiązywał zakaz używania hitlerowskiego powitania, co miało być oznaką ich wykluczenia ze społeczności niemieckiej. Opór przeciwko stosowaniu powitania skutkowal represjami ${ }^{14}$.

Powitanie nazistowskie to przykład jednego z wielu zapożyczeń ze świata antycznego, niemniej jednak inspiracja okresem starożytnym najbardziej widoczna jest w architekturze Trzeciej Rzeszy, której zostanie poświęcona dalsza część artykułu.

\section{Styl neoklasyczny w architekturze Trzeciej Rzeszy $y^{15}$}

Plany opanowania Europy, a w końcowym efekcie także całego świata, opierały się na chęci utworzenia czystej rasowo, aryjskiej Wielkiej Rzeszy Niemieckiej. O potędze tego państwa miał świadczyć również jego wygląd architektoniczny. Architektura odgrywała szczególną rolę propagandową w państwie narodowosocjalistycznym. Widać to na przykładzie projektów czy też budynków, które zdążyły powstać za czasów Trzeciej Rzeszy. W nurcie architektonicznym tego okresu dominował monumentalizm oraz inspiracja stylem klasycznym.

Naziści otwarcie przyznawali się do inspiracji światem antycznym. Wyraźnie nawiązywali do wzorców rzymskich i greckich. Było to motywowane nie tylko zachwytem nad sztuką klasyczną, lecz przede wszystkim chęcią stosowania sprawdzonych metod świadczących o wspaniałości dawnych cywilizacji16. Z tego powodu wznosili monumentalne budowle, które rzeczywiście mogły sprawiać wrażenie, że ma się do czynienia z potężnym narodem, któremu nic nie stoi na przeszkodzie do osiągnięcia swych celów. Gigantomania nazistowskiego reżimu miała też inne

14 R. S. Rose, Krytyczny stownik..., s. 193-194.

15 Określenie styl neoklasyczny w odniesieniu do architektury narodowosocjalistycznej pochodzi od Alberta Speera - architekta Adolfa Hitlera. Por. A. Speer, Wspomnienia, tłum. M. Fijałkowski et al., Warszawa 1990, s. 79.

16 I. Witkowski, Germania. Plany Trzeciej Rzueszy na okres powojenny, Warszawa 2006, s. 149. 
podłoża. Była wyrazem planów Führera, o których jeszcze nie mówił na głos - chęci podbicia całego świata ${ }^{17}$. Wznoszone budowle przez tysiąclecia miały być wyrazem potęgi Wielkiej Rzeszy Niemieckiej:

Hitler lubił oświadczać, że wznosi budowle, by przekazać następnym pokoleniom swoją epokę i jej ducha. Ostatecznie, mówił, o wielkich epokach historycznych przypominaja przecież tylko monumentalne budowle. Co pozostało po imperatorach cesarstwa rzymskiego? Co świadczyłoby dzisiaj jeszcze o ich istnieniu, gdyby nie ich budowle? W historii narodów zdarzają się co pewien czas okresy słabości, wtedy właśnie budowle zaczynają mówić o dawnej potędze. Oczywiście nowa świadomość narodowa nie da się zbudzić tylko dzięki temu. Ale kiedy po długim okresie upadku ponownie ożyje idea wielkości narodowej, wówczas pomniki przeszłości oddziałuja najsilniej ${ }^{18}$.

Dla wodza najwspanialszą antyczną cywilizacją byli Grecy. Zachwycał się ich kulturą oraz architekturą. Oczywiście, należy wspomnieć, że miał on na myśli lud grecki zwany Dorami, których uważał za przodków Aryjczyków. Przyczyniło się do tego propagowane w Trzeciej Rzeszy przekonanie, że plemię Dorów było pochodzenia germańskiego ${ }^{19}$. Ponadto Hitler wzorował się także na imperium rzymskim.

Najwyraźniej inspiracje antykiem widać na przykładzie budowli powstałych w Trzeciej Rzeszy. Należy do nich kompleks zjazdowy partii NSDAP w Norymberdze składający się m.in. z Zeppelinfeld - centrum zjazdowego; oraz Pola Marcowego (Märzfeld) - placu, na którym odbywały się defilady Wehrmachtu. Projekt kompleksu został zlecony głównemu architektowi Hitlera, Albertowi Speerowi. Prace budowlane rozpoczęto w 1934 roku. Ostatecznie ogromna kamienna budowla w stylu neoklasycznym miała 390 metrów długości, 24 metry szerokości, a jej trybuna wzorowana była na ołtarzu pergamońskim ${ }^{20}$.

Speer jawnie mówił o inspiracji światem starożytnym. Wielokrotnie podczas swoich podróży do Grecji i Rzymu szukał wśród antycznych budowli natchnienia dla projektów przeznaczonych dla Rzeszy ${ }^{21}$. Podążając

17 A. Speer, Wspomnienia, s. 87-88.

18 Ibidem, s. 71.

19 Ibidem, s. 120.

20 Ibidem, s. 70-71.

21 Ibidem, s. 80, 178.

Agnieszka Wypiorczyk · Antyk jako źródło inspiracji w hitlerowskich Niemczech 
za słowami Führera - „[p]otrzebujemy wspaniałego stylu. Ten styl trzeba stworzyć" - Speer wykształcił swój własny kierunek w architekturze ${ }^{22}$. Styl ten określił mianem neoklasyczৃnego, argumentując to tym, iż nawiązuje do stylu doryckiego. Była to również kontynuacja dzieła Paula Ludwiga Troosta, a zarazem hołd dla monachijskiego architekta Hitlera, zsyntetyzowana z puryzmem i monumentalizmem stylu Heinricha Tessenowa ${ }^{23}$.

Inspiracji światem antycznym Speer nie ograniczał jedynie do wyglądu budynków w momencie powstania. Chciał on, by - tak jak ruiny starożytnych świątyń - również i ruiny jego budowli po wielu latach zachowały piękno i chwałę. Natchnął go do tego widok zgliszcz podczas prac wyburzających przed budową kompleksu partyjnego. Wystające żeliwne druty zainspirowały architekta Rzeszy do opracowania tzw. teorii wartości ruin ${ }^{24}$. Miała się ona przyczynić do „tworzenia pomostu do przekazywania tradycji” przyszłym pokoleniom ${ }^{25}$ :

[J]est nie do pomyślenia, by rdzewiejące zwaliska gruzów przekazywały owe heroiczne inspiracje, które miał na myśli [Hitler], mówiąc o monumentalnych dziejach przeszłości. Ten dylemat rozwiązać miała moja „teoria": stosowanie specjalnych materiałów oraz uwzględnienie szczególnych układów statycznych powinno umożliwić wznoszenie budowli, które jako ruiny, po setkach lub (jak liczyliśmy) tysiącach lat, będą podobne na przykład do wzorców rzymskich ${ }^{26}$.

Pomysł ten początkowo spotkał się z krytyką ze strony partyjnych kolegów, ponieważ uważali, że Speer już na początku Tysiącletniej Rzeszy wliczał w rachubę jej upadek, jednakże spotkał się z poparciem Hitlera, który poprawnie odczytał zamiary architekta, a także zarządził, by najważniejsze budynki Rzeszy były wznoszone na podstawie tej teorii ${ }^{27}$.

Kolejnym przykładem monumentalnego budynku Trzeciej Rzeszy, nawiązującym do wzorów antycznych, jest Stadion Olimpijski w Belinie (Olympiastadion). Zaprojektował go Werner March, który zainspirował się rzymską koncepcją amfiteatru, a w głównej mierze Forum Trajana ${ }^{28}$.

22 A. Hitler, Rozmowy przy stole..., s. 97.

23 A. Speer, Wspomnienia, s. 79.

24 Niem. Ruinenwerttheorie.

25 A. Speer, Wspomnienia, s. 72.

26 Ibidem.

27 Ibidem.

28 I. Witkowski, Germania..., s. 150. 
Ponadto hala kongresowa (Kongresshalle) w Norymberdze również przypominała swoim wyglądem antyczne budowle. Została ukończona jedynie w stanie surowym. Projekt zakładał, że pomieści 50 tys. ludzi. Zewnętrzna elewacja wzorowana była na rzymskim Koloseum. Dach wykonano w większości ze szkła, aby nadać budynkowi wrażenie lekkości. Na wzór grecki hala otrzymała kształt podkowy, żeby nie sprawiać wrażenia stadionu. Ogólnie była o 70\% szersza i 30\% dłuższa od rzymskiego pierwowzoru $^{29}$.

Projekty przebudowy Wielkiej Rzeszy Niemieckiej nie ograniczały się jedynie do pojedynczych kompleksów budynków. Reformie urbanistycznej miały zostać poddane całe miasta. Planowano przebudować je według rzymskiej koncepcji forum, tj. podłużnego placu otoczonego neoklasycznymi gmachami budynków państwowych ${ }^{30}$. Najbardziej monumentalne forum wraz z posagami na gmachach budynków miało powstać w Berlinie $^{31}$. Berlinowi przypadła również nowa, ogromna rola w wielkim imperium niemieckim. Jako stolica całego świata - ze zmieniona, bardziej odpowiadającą tej funkcji nazwą Germania - miał on pełnić funkcję polityczno-reprezentacyjna ${ }^{32}$. Hitler w swoich wypowiedziach podkreślał, że Berlin będzie przywodził na myśl wyłącznie starożytne imperia, takie jak Egipt, Babilon czy Rzym ${ }^{33}$. Plany utworzenia Germanii miały przywrócić Niemcom narodową dumę, nadszarpniętą wskutek przegranej wojny i postanowień traktatu wersalskiego ${ }^{34}$. Szczególna rola została przypisana także innemu niemieckiemu miastu - Monachium. Plany jego przybudowy zakładały, że stanie się ono nową kolebką kultury ${ }^{35}$.

Jak wspomniano, inspiracja światem starożytnym nie odnosiła się jedynie do architektury. Na uwagę zasługują również inspirowane grecko-rzymskimi wzorcami rzeźby Arno Brekera, przedstawiające ucieleśnienie idealnego Aryjczyka ${ }^{36}$. Wiązało się to z przywołanym wcześniej przekona-

29 Ibidem, s. 169.

30 Ibidem, s. 150.

31 Ibidem.

32 Ibidem, s. 170-197; R. S. Rose, Krytyczny stownik..., s. 83.

33 R. S. Rose, Krytycæny stownik..., s. 83.

34 Ibidem, s. 84.

35 I. Witkowski, Germania..., s. 170-197.

36 Zob. J. Chapoutot, Wiek dyktatur. Faszyzm i reżimy autorytarne w Europie Zachodniej (1919-1945), tłum. A. Purchla, Warszawa 2012, s. 187. 
niem o tym, że jakoby przodkami Aryjczyków mieli być Grecy. Według ideologów Trzeciej Rzeszy, wskutek tego pokrewieństwa naród niemiecki posiadał wyjątkową zdolność odbierania, rozumienia i odczuwania ducha kultury antycznej ${ }^{37}$. Z tego też powodu sztuka narodowosocjalistyczna - aby popierać ten pogląd - musiała nawiązywać do helleńskiego kanonu, który, jak twierdzili propagandziści, odzwierciedlał cechy aryjskiej rasy ${ }^{38}$. Zaczerpnięty ze świata starożytnego hellenistyczny ideał wysportowanej sylwetki był silnie promowany w państwie nazistowskim, szczególnie wśród młodzieży, którą zachęcano do ćwiczeń fizycznych. Taka aktywność miała również propagandowy wymiar - po pierwsze jej zadaniem było obudzenie u młodych ducha walki, po drugie miała przygotować ich do ciężkiej wojny na froncie.

Inspiracje antykiem widać również w prologu filmu dokumentującego Letnie Igrzyska Olimpijskie z 1936 roku w Berlinie - Olimpiada (1938) w reżyserii Leni Riefenstahl. Jako reżyser, chcąc ukazać nawiązanie do tradycji greckich i ich rzekome kontynuacje w hitlerowskich Niemczech, zawarła sekwencje przedstawiające ateńskie świątynie, rzeźby starożytnych bogów, antycznych atletów oraz symboliczne przekazanie ognia olimpijskiego z czasów antycznych do czasów współczesnych. Igrzyska te miały wyjątkowe, propagandowe znaczenie. Były okazją do pokazania potęgi państwa narodowosocjalistycznego na arenie międzynarodowej. Z tego powodu rząd narodowosocjalistyczny na szeroką skalę zaangażował się w organizację tego wydarzenia. Oczywiście posłużyło mu ono również do rozpowszechniania ideologii poprzez wzbogacenie idei olimpijskiej nazistowskimi symbolami i rytuałami ${ }^{39}$. Było to możliwe, gdyż wiele elementów ideologii volkistowskiej dawało się łatwo wkomponować w zwyczaje olimpijskie ${ }^{40}$. Tak więc, zamiast oliwnymi gałązkami, zwycięzcy byli koronowani wieńcami dębowymi, które symbolizowały niemiecką istotę, siłę i gościnnośćc ${ }^{41}$. Przysięgę olimpijską, którą niemiecka reprezentacja składała pod flaga, wzbogacono

37 Zob. H. Bernett, Nationalsozialistische Leibeserziehung. Eine Dokumentation ibrer Theorie und Organisation, Schorndorf 1966, s. 32-33.

38 Zob. K. Chiżyńska, Inspiracje grecko-rzymskie w ideologii nąৃistowskiej, „Collectanea Philologica” 2013, t. XVI, s. 167.

39 Zob. M. Stępiński, Na drodze do XI Igrzysk Olimpijskich w Berlinie. Sport między ideałami ruchu olimpijskiego a politykeq III Ržeszy. CZ̨eść I, „Przegląd Zachodniopomorski” 2012, z. 1, s. 13.

40 Ibidem, s. 15.

41 Ibidem, s. 10. 
o fragment mówiący o dyscyplinie oraz posłuszeństwie, a na otwarcie igrzysk rozbrzmiewał specjalnie na tę okazję odlany dzwon olimpijski ${ }^{42}$. Część ze starannie zaplanowanych przez nazistów rytuałów pojawiających się na igrzyskach olimpijskich w 1936 roku zachowała się do dziś, chociażby najpopularniejszy symbol igrzysk - znicz olimpijski. To właśnie wówczas zapoczątkowano tradycję sztafety z ogniem olimpijskim, która obecnie utraciła swoje faszystowskie podłoże $\mathrm{e}^{43}$.

Na podstawie omówionych przykładów widać wyraźnie, w jak dużym stopniu narodowi socjaliści inspirowali się światem starożytnym. Można by jeszcze długo wymieniać projekty budowli, które nie zdążyły powstać, a także monumenty, które do dziś świadczą o tym ponurym okresie w historii Niemiec. W Trzeciej Rzeszy tradycje antyczne nie były kontynuowane, lecz wykorzystywane do celów propagandowych. Odwołując się do świata antycznego, naziści chcieli stworzyć iluzję wielkiego imperium. Przez swoje rozmiary, a także totalny charakter ich gigantyczne, megalomańskie projekty nie były już jednak przykładem stylu klasycznego, lecz stały się jego karykatura. Zamiast świadczyć o potędze państwa, wyrażały pychę i wygórowane ambicje. Upolityczniona architektura stała się symbolem upadku Tysiącletniej Rzeszy, która przetrwała jedynie 12 lat.

\section{Bibliografia}

Bernett H., Nationalsozialistische Leibeserziehung. Eine Dokumentation ihrer Theorie und Organisation, Schorndorf 1966.

Chiżyńska K., Inspiracje grecko-rzymskie w ideologii nazistowskiej, „Collectanea Philologica” 2013, t. XVI, s. 159-173.

Chapoutot J., Wiek dyktatur. Faszyzm i reżimy autorytarne w Europie Zachodniej (1919-1945), tłum. A. Purchla, Warszawa 2012.

Hitler A., Moja walka, tłum. I. Puchalska, P. Marszałek, Krosno 1992.

42 Ibidem.

43 K. Chiżyńska, Inspiracje grecko-rzymskie..., s. 169. 
Hitler A., Rozmowy przy stole 1941-1944. Rozmowy w Kwaterze Gtównej zapisane na polecenie Martina Bormanna przez jego adiutanta Heinricha Heima, tłum. zespół, red. S. Dejkało, Warszawa 1996.

Maciejewski M., Kult Führera wśród narodowych socjalistón do 1933 r., [w:] Faszyzm niemiecki r.perspektywy pótwiecza, red. A. Czubiński, Poznań 1985, s. 53-78. Rose R. S., Krytyczny stownik mitów i symboli nazizmu, tłum. Z. Jakubowska, A. Rurarz, Warszawa 2006.

Speer A., Wspomnienia, tłum. M. Fijałkowski et al., Warszawa 1990.

Stępiński M., Na drodze do XI Igrzysk Olimpijskich w Berlinie. Sport między ideatami ruchu olimpijskiego a polityka III Rzeszy. Czesśc I, „Przegląd Zachodniopomorski” 2012, z. 1, s. 11-43.

Wieliczka-Szarek J., III Rzesza. Narodziny i zmierz̨ch szaleństwa, Kraków 2006. Witkowski I., Germania. Plany Trzeciej Rzeszy na okeres powojenny, Warszawa 2006.

Antyk jako źródto inspiracji w bitlerowskich Niemczech

W artykule podjęto próbę wskazania i opisania kilku przykładów inspiracji światem antycznym w Trzeciej Rzeszy. Inspiracja ta nie ograniczała się jedynie do rytuałów wzorowanych na czasach antycznych, takich jak np. pozdrowienie nazistowskie, będące kalką salutu rzymskiego. Była to w głównej mierze inspiracja czerpana z architektury. Budynki powstałe w hitlerowskich Niemczech wzorowano na antycznych świątyniach i zabytkach. Autorka przywołuje i omawia m.in. kompleks zjazdowy partii NSDAP w Norymberdze, inspirowany ołtarzem pergamońskim; Stadion Olimpijski w Berlinie wzorowany na Forum Trajana czy też halę kongresową w Norymberdze imitującą rzymskie Koloseum. Ogromne kompleksy monumentalnych budowli w stylu neoklasycznym, które miały świadczyć o potędze Rzeszy, finalnie stały się symbolem upadku oraz pychy.

\section{Antique as a source of inspiration in Nazi Germany}

The article presents the description of several examples of inspiration from the ancient world in the Third Reich. This inspiration was not only limited to rituals from ancient times, such as, e.g. Nazi salute, which was a copy of a Roman salute. 
It was predominantly an inspiration in the architectural context. Buildings, which were built in the Nazi Germany, were modelled on ancient temples and monuments. The author of the article shows and discusses, such examples as the Nazi party rally grounds in Nuremberg, which was inspired by Pergamon altar; Olympiastadion in Berlin modelled on Trajan's Forum or the Congress Hall in Nuremberg, which was imitating the Roman Colosseum. This huge complexes of monumental buildings in the neoclassical style were supposed to show the power of the Third Reich. They eventually became a symbol of fall and pride. 